\title{
A Comparative Approach to Fictions Named Malone Dies and Lying Down to Die
}

\author{
By Elmas Sahin*
}

This paper argues that the novels called contemporary Turkish woman writer Adalet A ğaoğlu's Lying Down to Die (1973) and English writer Samuel Beckett's Malone Dies (1950) have significant intertextual similarities to each other as texts of postmodern fiction. When compared and contrasted in terms of comparative literature Lying Down to Die also is within a network of references to, quotations from, and plagiarisms of Malone Dies, and every text is an intersection of others as forms and contents.Ağaoğlu's novel has some postmodern and intertextual characteristics such as form and content with English writer Beckett's fiction. Aysel, an old woman waiting for her death in her bed in a hotel room, like Malone who almost is unable due to an illness in a hospital room, asylum, mental hospital, a shelter or simple a space in his mind, his body doesn't respond anymore, the parts of his body doesn't work. Both characters also think about past, moment and future, writes, waits for death from similar perspectives although one is a woman, the other is a man. This study explores that the characters mark out the thin line between life or death, question their existence, play with readers by ironic expressions, in terms of comparative literature.

\section{Introduction}

Absence of mutual interactions between literary texts is an inevitable fact. Each author must have benefited to some extent the earlier writer or text. Relationships between texts sometimes are open, sometimes in the form of various images and symbols. Thanks to continuous advances in the field of interactions taking place this type, and a variety of new concepts every day is moving memories.

From classical period to the postmodern era, these concepts such as romanticism, realism, naturalism, surrealism, nihilism, existentialism, structuralism, and deconstruction emerged as a result of this interaction, and contributed to the literature through the action-reaction type. Intertextual relations and references to each other of the works have prepared a ground to emergence of the concepts 'comparative literature' and 'intertextuality.'

*Assistant Professor, Cag University, The Department of Turkish Language and Literature, Turkey. 
Interactions cannot be underestimated as a result of the effect of technology, not only national, international dimensions are moved. Thus, the authors to reach universal themes by giving up local themes enter into an interaction with each other.

Such an intertextual relationship appears in Adalet Ağaoğlu's works, one of the important figures of contemporary Turkish literature. Like the British writer Samuel Beckett affected by French author Proust, Ağaoğlu has been affected by Beckett as well. In this study, their works named Malone Dies (1951) in Beckett's Trilogy and Lying Down to Die (1973) in Ağaoğlu's the Trilogy Dar Zamanlar (Hard Times) will be examined according to the theory of intertextuality in the light of postmodernist tradition and besides, the concepts intertextuality and postmodernism will be discussed briefly here in terms of these two postmodern fictions.

\section{Postmodernism}

The term postmodernism emerged after the 1950s as an artistic, philosophical and cultural movement. Historical sense, although not quite as easy to predict when it started as a word that has a complex structure, postmodernism, as an academic discipline in the mid-1980s, has started to appear in all disciplines such as art, music, film, literature, sociology, architecture, communications, fashion, technology.

Postmodernism focuses on a culture of pluralism, rises on Modernism, it means 'more modern' or 'completely new' this, more extensive changes occurring throughout the world in a deeper part. Postmodernism, in a way that the point of what is going with something.

Postmodern fictions carry features such as parody, irony, play, display, tragedy, deconstruction, loss of self, self-seeking, loss of consciousness, ontological questions very significantly. The postmodern protagonists live together 'past, present and future' in the same time.

As Hassan Ihab (1961) also says the most important feature of a postmodern work reflects in the words of the heroes, they are in luck and equipping of the absurd actions, they are devoid of moral behaviour, alienated from the environment, and life is full of irony and contradictions, with limited information (115-18). Postmodernists believe in the truth of man's ideas and experience. The facts or lines, outside of human thoughts and feelings rather than thoughts and experiences brought by an individual, lie in the culture. Postmodern works have no plot, focus on individual's stream of conscious

Shortly postmodern writers as postmodern styles use nostalgia and flash back techniques, new formations and styles of the former type of re-production (film/TV types, images, Medical facilities, colours, clothes and hair styles, advertising images) in the context of pop-culture images of a nostalgic past, through fantasies referred to a the history ot the past, blended with historical depictions of nostalgia, historical sense, absence, the weakening of ties with its past in the contemporary social system, a permanent "moment" to live in the 
forth coming to the rapid cultural, and historical monuments, suppositions for future.

\section{Intertextuality}

Intertextuality, all of which is interpreted as the basis or the creation of a text in a text or other text, a relationship between the complex. This is similar to or as opposed to show up in cross-cultural relations. In a way the writer reinterprets the texts that he or she is influenced.

This is the Latin word which means to intermingle, derived from the word intertexto. Intertextuality, the first time in the 1960s was used by the French theorist Julia Kristeva. In the essays called Word, Dialogue, and Novel. Kristeva, on the author's 'effects' and the text 'resources,' tries to break the principles in the traditional subjects. The author is no longer just a product of a literary work. There are also links to other works in addition to its own structure of the language. According to Kristeva, "A text is the absorption and transformation of one another, a mosaic of quotations." (Kristeva 1980, 66) or "it cannot be independent of any text in another text." (Hawkes 1989, 144).

In intertextuality some words may contain a reference to the other texts. There is nothing outside of its predecessor, the author will write or recreate a new text. Everything is written.

Here, the author, re-written to deal with; excerpts from the work of the former re-melt and knead the falls in its own pot. First, in light of intertextual references, past a modern work, in different studies from different sources to reach some concrete postmodern establish a work relationship more general things. Any genre, era, or a literary tradition in terms of style makes reference to the thematic aspects.

Style of a text is an important point in terms of intertextuality. The aim is to enrich the text with new meanings ascribed to modern writers. In contrast, postmodern writers want to ascribe the new text before existing text. So logically the existing text and associate it works. While the focus of the Modernists is on 'new texts,' postmodernists' focus is the 'ancient texts.' Postmodern writer realizes that a new literary genre is literary text as an open text, textual meta-text as a thinker and he/she converts it to the other.

As a research technique, the concept of comparative literature together with intertextuality also is very often used in cultural studies. Both comparative literature and intertextuality need to trace the relations between the two works or more go to the path of taking over and review the interactions between objects.

In short, while intertextuality focuses on the relationships between texts, comparative literature goes back in a much more national and international relationships that expose between domestic and foreign literatures, we can say that it is seen as a critical tradition. Comparative literature studies the similarities and differences between the local and traditional context, this concept is involved in the interactions between both writers and texts. 
As a result if a literary text is a reflection of other literary text, in this context, to a variety of people to read works of literature there are some impacts between in texts some. Intertextuality seems as a powerful tool especially in postmodern texts. In this study as we compare and contrast Samuel Beckett's Malone Dies (French-1951, English 1956) and Adalet Ağaoğlu's Lying Down to Die (1973) are samples of intertextual and postmodern perspective, Ağaoğlu's novel is reflected in both theme and style of of Beckett's fiction.

\section{Malone Dies and Lying Down to Die: A Comparative Approach}

A ğaoğlu writes Lying Down to Die nearly twenty years later from Samuel Beckett's Malone Dies. Beckett tells collapse of cognitive and physical self in his trilogy including Molloy, Malone Dies and Unnamable. In Malone Dies, the second book of his trilogy, the protagonist Malone expects to die in a room that he does not know where he is. This is in anticipation of various stories he tells. He focuses on things. He is in search for identity. He is disabled; he can do nothing without a stick. Moreover, he waits for dying in his bed, but he is still alive at the end of the work.

However Ağaoğlu also tells Aysel's story, an Associate Professor at a university in Ankara, who wants to die in a hotel room in Lying Down to Die in the first book of her trilogy titled Hard Times including Lying Down to Die, One Wedding Night, and No. the protagonists Malone and Aysel wait for dying in the same intertextual postmodern approaches. Both characters are in some kinds of quests, try to live past, moment and future together in the similar ways. They appear as a character on the verge of physical destruction in selfseeking, and helplessness.

When we examine these two fictional novels in terms of intertextual relations, we will see that Lying Down to Die emerges under the influence of postmodernism in intertextual impacts from Malone Dies. Both Beckett and Ağaoğlu's characters expect to die in a small room. Why do they stay in a room? Why do they want to die? Do they really dream of dying? Is death of salvation for them? When will the death come? Both of them cannot fully know the answers to these questions. More precisely, they are not aware of anything. They are incapable, in mental depression and physical collapse. Malone is crippled, waits for death in his bed, Aysel is not crippled, but she feels herself incapable, and crippled like Malone.

Both of them do not know when the death comes for them. Malone and Aysel feel weak, helpless, strange, stiff or in their beds, and their minds are so complex, they do not know what to do or what to want. For instance, they are afraid of dying although they want to die, they cannot succeed the death, Aysel in deathbed gets up and goes out the hotel at the end of the novel, we cannot know where she goes, or why she gives up dying. Malone cannot also die at the end, and they astonish us by surprising endings. 
We also think that they will die at the end while reading these novels. This is a trick, they play us. Malone says:

I SHALL SOON BE QUITE DEAD AT LAST IN SPITE OF ALL. PERHAPS next month. Then it will be the month of April or of May. For the year is still young, a thousand little signs tell me so. Perhaps I am wrong, perhaps I shall survive Saint John the Baptist's Day and even the Fourteenth of July, festival of freedom. (Beckett, 1)

Aysel also speaks in a similar way, she is not crippled, but so weak and she waits for dying:

I lay motionless in bed. I entered a warm room to die. My naked body is clean, still cold on the starched linens. I'm tremble under the blanket. This chill brings me death, and death away. Perhaps a death shake. But I understand, this shimmer shows me that I wasn't dead. (Ağaoğlu, 26)

Malone is also like Aysel is naked in bed and just waits for the death in that so.

I am naked in the bed, in the blankets, whose number I increase and diminish as the seasons come and go. I am never hot, never cold. I don't wash, but I don't get dirty. If I get dirty somewhere I rub the part with my finger wet with spittle. (Beckett, 7)

Both Malone and Aysel question themselves in a consciously or unconsciously way. Words randomly drop out. Words mean nothing, are just said to be said. Samuel Becket and Adalet Ağaoğlu give here streams of consciousness of characters by simple inner dialogues, but impressive sentences in similar way.

I shall not watch myself die, that would spoil everything. Have I watched myself live? Have I ever complained? Then why rejoice now?... "What was that I said? It does not matter. (Beckett, 1-2)

I did not know that I would also lie down to die around eight in the morning. I was sensing, but delaying it. I wonder, was that so? Did I not know really? Have I decided it is in a consequence of incompetence? (A ğaoğlu, 45)

On the one hand, they want to die, the other hand to delay the death, but they want to extend their lives by mentioning about objects in the room, and their pasts and futures they hesitate about to die or not to die:

My desire is henceforward to be clear, without being finical. I have always wanted that too. It is obvious I may suddenly expire, at any 
Vol. 1, No. 2 Sahin: A Comparative Approach to Fictions Named Malone Dies...

moment. Would it not then be better for me to speak of my possessions without further delay? Would not that be wiser? (Beckett, 3)

On the other Aysel also speaks in the same way. 'Because I have not yet completed my death what must I do? Should I wait.' (Ağaoğlu, 101) When we compare and contrast these two works from top to end. We meet lots of similarities. One of the most interesting ones is quest of 'self' Aysel as a female like a male sex, Malone is free, and in search of self.

A sense of belonging, self-seeking, to come back and forth between real and dream and weakness of consciousness cover narrators of the novels 'Malone and Aysel', their minds are very complex and busy. Where are they? How did they come there? One of them is a man, the other one is a woman, but their common feature is to wait for death in a small room. In particularly it is clear for Malone. Malone does not know exactly where that he is, but he tries to estimate.

I do not know quite what floor I am on, perhaps I am only on the mezzanine. The doors banging, the steps on the stairs, the noises in the street, have not enlightened me, on this subject. All I know is that the living are there, above me and beneath me. It follows at least that I am not in the basement. (Beckett, 44)

However, Aysel self goes to a hotel, and remains on the sixteenth floor of the hotel. She comes consciously; therefore, she knows where she is. However, she is incapable of knowing, how many days she has stayed there, or she will stay there.

We full went sixteen-flats by the lift. We got on the sixteenth floor. I am walking after the boy to show room to me. He passed a short corridor. He stood in front of a room. Therefore, I stopped. He opened the door and we entered. I turned all lights off. I quickly undressed. I opened the bed in the corner. I went in naked. I lay dying. (A ğaoğlu, 7)

While these two postmodern individuals deal with their environments on the one hand question themselves:

Perhaps I came in for the room on the death of whoever was in it before me. I enquire no further in any case. It is not a room in a hospital, or in a madhouse, I can feel that..... No, this is just a plain private room apparently, in what appears to be a plain ordinary house. I do not remember how I got here. In an ambulance perhaps, a vehicle of some kind certainly. One day I found myself here, in the bed. Having probably lost consciousness somewhere, I benefit by a 
hiatus in my recollections, not to be resumed until I recovered my senses, in this bed. (Beckett, 5)

The sound of a vacuum cleaner is heard outside. Floor servant must have started to clean rooms. Is she not late to work? I remember. I forgot hanging "please don't disturb" on the door of the room. Pity .I should hang it. But I cannot get up anymore. I lay dying. (Ağaoğlu, 61)

Waiting for the death both of them tell stories about their past and futures, and they live past in present in postmodern nostalgia. They often speak to themselves. They return a past, live a present or estimate on their futures. Sentences they desire silence. Sometimes they are afraid of silence, and sometimes they're startled by a voice outside. The sounds of outside world sometimes go them to the past; sometimes lead them to their childhood and youth in their deathbeds. Malone cannot get himself in the past:

The old fog calls. Now the case is reversed, the way well charted and little hope of coming to its end. But I have high hopes. What am I doing now, I wonder, losing time or gaining it? (Beckett, 4)

Aysel like Malone both thinks and waits for death in her bed, her mind is complex.

Fortunately I am in one of the top floors. I do not hear the noise of the city. I only hear murmurs of the vacuum cleaner in the corridor. I wish I'd had the mind to shut off the middle door. Must I get up and close it? Beside I hang on the plate. But I cannot get up. Without anything in this bed I lay down not getting up. (Ağaoğlu, 62)

Malone, on his deathbed while waiting even though a foot is in the grave, semi-unconscious, dreams about writing something at the time. Aysel also is like him. Will they die? What are they saying? Is their consciousness lost or not? While they tell something how much sincere are they, or how reliable? Always leave the reader in doubt and they play games with the readers:

When I have completed my inventory, if my death is not ready for me then, I shall write my memoirs... My bed is by the window. I lie turned towards it most of the time. I see roofs and sky, a glimpse of street too, if I crane. I do not see any fields or hills. And yet they are near. But are they near? I don't know... I do not see the sea either, but I hear it when it is high. (Beckett, 6)

I do not know what I think. I am stirring. Various words are forcing my brain. They are not a kind of a sentence by coming up side by side. (Ağaoğlu, 102) 
Both of them describe their memories in their beds. They often live past in present. They do not give up from the past. The concept of time is eliminated. There are only words, time literally stops. They remember the past like the first day. However, there are hesitations about their location. Animals as well as objects also have an important place in his memoirs; generally, they symbolize fear for Aysel and Malone:

Yes, I got great amusement, when young, from their so-called silence. The sound I liked best had nothing noble about it. It was the barking of the dogs, at night, in the clusters of hovels up in the hills, ... It came down to me where I lay, in the house in the plain, wild and soft, at the limit of earshot, soon weary. The dogs of the valley replied with their gross bay all fangs and jaws and foam. (Beckett, 31)

I as five years old. In the garden, around grass I saw a beautiful flower in a terrible way. According to me, for I had never seen a flower, which is nice. I stuck out my hand. I wanted to touch it. Touch and touch... and then I yelled in pain. It was not the flower, but a poisoned animal ... (Ağaoğlu, 337)

Sounds in real and dream are enriched by several connotations in these two individuals' minds lying to die. Like their feet, their ears are also defective. They cannot fulfil their functions in full:

Note then, without emotion, that of late their hearing seems to have improved. Oh not that I was ever even incompletely deaf.But for a long time now I have been hearing things confusedly. (Beckett, 31) My sleep is mixed by wakefulness. As if I was lying awake with my one eye. My one ear is deaf; the other is open as well. I am thinking of, the fact that my sleep is awake is not new. No. (Ağaoğlu, 301)

These postmodern characters remember past better than present. They very often question moment in the bed when are there in it? What time is it? They do not know:

I know the year of my birth, I have not forgotten that, but I do not know what year I have got to now. But I think I have been here for some very considerable time.... I tremble a little, but only a little. The groaning of the bedstead is part of my life. (Beckett, 8-9)

The room is getting hot. Behind the scenes the sun must be born. I wonder what time it is. Eight, nine, and maybe ten... (Ağaoğlu, 25)

Although they wish to sleep, they are afraid of dying. On the one hand the desire to die, on the other hand the fear of death wraps Aysel and Malone heavily. Sleeping is like to semi-die. Constantly they talk to themselves not to sleep, or they deal with things their around. 
I fell asleep. But I do not want to sleep. There is no time I sleep in my time-table. I do not want... Live and invent. I have tried. I must have tried. Invent. It is not the word. Neither is live. No matter. I have tried. (Beckett 18)

In the armchair, according to parts of body that touch eyes I am naked. Finally, however, I thought to dress up. I wanted to dress up only to have done something, in order to stall myself against my death delayed. I mean, without it, I was asleep in the chair. I was nearly fainted. (Ağaoğlu, 297)

They fail to express themselves. They are in a constant ambivalence about the death. They behave as if there was one near them. They struggle between life and death by fragmented salves without any reasons:

I say living without knowing what it is. I tried to live without knowing what I was trying. Perhaps I have lived after all, without knowing.... Of myself I could never tell, any more than live or tell of others. (Beckett, 18-19)

I wonder, I take my last cigarette before I die? I want to smoke very much a cigarette. Why will I not smoke then? (Ağaoğlu, 105)

One of the postmodern approaches is also the concept 'I.' They have no any clues about who they are or what they are:

But as far as I myself am concerned the same necessity does not arise, or does it? And yet I write about myself with the same pencil and in the same exercise-book as about him. It is because it is no longer I.' (Beckett 32) 'For a moment, who or where I am, I do not know what to do. (A ğoğlu, 297)

Instability of individual, searching of self in both novels is an important intertextual similarity. There is the concept "I" in search of characters from beginning to the ending. They often talk to themselves, they are alone, and isolated from outside environment or the society.

What matter whether I was born or not, have lived or not, am dead or merely dying, I shall go on doing as I have always done, not knowing what it is I do, nor who I am, nor where I am, nor if I am. (Beckett 52)

I can distinguish that the curtains of the room is dark green. Does it appear dark because the room is dark, I wonder? At one point, as if the sun was behind them. Now, no light, does not say what there is outside of time. I do not have any clue. Must I open the dark green curtains? Do not I ?... I'm not in the bed, but in an armchair. Must I open the curtains? Here's all the same armchair, I ask this question 
Vol. 1, No. $2 \quad$ Sahin: A Comparative Approach to Fictions Named Malone Dies...

without installing the real meaning. Because I have neither willing nor unwilling to open the curtains. (Ağaoğlu, 147)

Time passing takes the "I" with it. Both characters also are unknown now:

That passed the time, I was time, I devoured the world. Not now, any more. A man changes. As he gets on. (Beckett 26)

I should struggle not to wake up. What a hopeless situation... I am still here, my dreams, and here is me and my dreams, in fact, I'm in a line between ' $I$ ' and situation here. This is a maddening line ... neither am I that, not this one. (A ̆gaoğlu, 297)

Aysel's room, just like Malone and is grey like death. This indicates one another sameness in terms of intertextual. The grey colour symbols a stifling and suspicious world that people imprisoned herself. Atmosphere and objects are gray in both two works as well.

The light is there, outside, the air sparkles, the granite wall across the way glitters with all its mica, the light is against my window, but it does not come through. So that here all bathes, I will not say in shadow, nor even in half-shadow, but in a kind of leaden light that makes no shadow, so that it is hard to say from what direction it comes, for it seems to come from all directions at once, and with equal force. (Beckett 46)

I pass under worn clothing and dull pants almost dividing the room,. I am looking at the walls, lying on either side of the door, that door painted grey like a prison door.. In any case, once upon a time the walls were whitewashed by parchment-coloured paint. (A ğaoğlu, 218)

The concept of nihilism has an important place in postmodernism. Almost all lines in the texts consist of nothingness. In fact, nothing is more real than existence in the works: 'Nothing is more real than nothing.' (Beckett, 199)

Did I not tell you? I did not say? I said nothing. At the coast of nothingness, so I keep, my mouth is open. (A ğaoğlu, 312)

\section{Results and Discussion}

Adalet Ağaoğlu's novel is an intertextual work when we compare Samuel Beckett's. It has lots of similarities except a few differences such as Aysel is a woman, and not crippled in reality, but Malone crippled cannot do anything without a stick. 
As a result, in Ağaoğlu's work we obviously see intertextuality as a postmodern novel influenced by Beckett. Ağaoğlu uses the name 'Molloy,' the protagonist of the first novel of Samuel Beckett's trilogy, in her novel. Ağaoğlu reflects this name Molloy in Aysel's mind in her deathbed. She clearly shows this effect in this text:

You smoke too much ... coughing ... Molloy ... endless fight? ... where is my fosfostimol (a pill), Whose was the sinister courtyard? ... Ivo ... Ivo ... Oh, my god! ... Okay. I will go to bed. Why will I not go to bed? As a Western thing, like a man, so ... (Ağaoğlu, 270)

In Lying Down to Die, the narrator, that is, the heroine of the novel, Aysel, is from eastern according to westerners like Beckett's heroes Molloy, Malone or Moran, she lies dying like a western. Here Both Ağaoğlu and Beckett's protagonists as well as postmodern intertextuality are two living individuals of our days alienated from the society, searching their selves, in afraid of life and death.

They cannot succeed in dying. Both they escape from their own selves and they are alienated from their world and environment. Both writers very often use the concepts such as 'do not know, but, no, maybe, perhaps, death, dark, sound and I.' Thus they make the reader think, and they provide fluency rather than tightening.

In addition, both the author's styles of language and sentence structure are simple and ironic. They prefer short sentences. However, they question life and death by making the readers think and they want the readers to complete the empties in the texts in the terms of meaning.

\section{Bibliography}

Ağaoğlu, A. (2004), Dar Zamanlar 1-Ölmeye Yatmak (Lying Down to Die), Istanbul: YKY.

Beckett, S. (1956), Malone Dies, New York: Grove Press

Hassan, I (1961), Radical Innocence, the Contemporary American Novel, New York: Harper and Row

Hawkes, T. (1989), Structuralism and Semiotics. Bungay: Routledge

Kristeva, J. (1980), "Word, Dialogue, and the Novel," in Leon S. Roudiez (ed), Desire and Language, Eng trans. Thomas Gora, 64-91, New York: Columbia University Press 
